\title{
Perspectives of health workers regarding primary health care delivery to the rural population in the Bothaville district*
}

\section{E. Janse van Rensburg \\ B.Soc.Sc. Hons.}

\&

\section{F. Steyn}

B.Soc.Sc.Hons.

\&

Z. Matebesi

B.A.Hons.

Centre for Health Systems Research \& Development University of the Orange Free State

\section{Abstract}

This article reports on the views of public health workers regarding recent changes in the delivery of primary health care to people living and working in the Bothaville rural area. These changes in mobile health care form part of the Initiative for Sub-District Support's programme to provide sustained, concerted support to sub-districts to bring about improvements in health care management and health care delivery. Main shortcomings of the recent changes were identified as inadequate transportation facilities in rural areas, insufficient information dissemination to rural dwellers and lack of farmers' participation in rural health matters. Furthermore, poor communication and co-operation between different public health services prevailed and the need for an integration of these services was emphasised.

Abstrak

Hierdie artikel doen verslag oor die sienings van publieke gesondheidswerkers rakende onlangse veranderinge in die lewering van primêre gesondheidsorg aan die plattelandse bevolking in die Bothaville distrik. Hierdie verandering in mobiele gesondheidsorg form deel van die Inisiatief vir SubDistrik Steun se program om volhoudende steun aan subdistrikte te verleen ten einde verbeteringe in gesondheidsorgverskaffing en -bestuur te verwesenlik. Hooftekortkominge van die onlangse verandering is as onvoldoende vervoermoontlikhede, ongenoegsame weergee van inligting aan plaasbewoners en gebrekkige deelname van boere in landelike gesondheid geïdentifiseer. Verder bestaan swak kommunikasie en samewerking tussen verskillende publieke gesondheidsdienste en die noodsaaklikheid vir ' $n$ integrasie van hierdie dienste is beklemtoon.

\section{Background to the study}

With the dawn of the new political dispensation in South Africa during 1994, the health sector set out for major reform by commencing on the implementation of a single comprehensive, equitable and integrated public health system in South Africa in the form of a National Health System (NHS). This pertained translating a fragmented system into a single government structure dealing with health, based on national guidelines, priorities and standards. All aspects of public and private health care delivery are co-ordinated in such a system and it is accountable to the people through democratic structures. The development of such a system is based on a Pri-

* The authors sincerely acknowledge the financial support of the Initiative for Sub-district Support (Health Systems Trust) for this project. 
mary Health Care (PHC) approach and therefore $\mathrm{PHC}$ has been accepted as the foundation of health care delivery in the country (African National Congress, 1994a: 45 \& African National Congress, 1994b: 19). An important component of the PHC approach entails delivering health care to historically neglected rural areas all over South Africa, which is done by a mobile clinic system, taking PHC to people living on farms.

The NHS policy in South Africa dictates the decentralisation of certain responsibilities for health services to provincial and municipal levels. To give effect to this mandate, a District Health System (DHS), in which responsibility for service delivery is entrusted to the district level, is in the process of establishment (African National Congress, 1994a: 44 \& 45; Government Gazette, 1997: 17; Free State Department of Health, 1998: 3 \& Van Rensburg et. al. 1998: 4\&5). A DHS could be defined as a vehicle for providing quality primary health care to everyone in a defined geographical area. It is a system of health care in which individuals, communities and all the health care providers of the area participate to improve health. Health districts form the building blocks of the NHS (Free State Department of Health, 1998: 3 \& Health Systems Trust, 1997: 3). DHS implementation thus means, in broad terms, the regionalisation of services and therefore dividing the country and in turn, the nine provinces of South Africa, into smaller administrative and service units. Authority and decision-making is devolved to district offices, while management autonomy is diverted, as far as possible, to health facility level.

In order to address the challenges of implementing the DHS at grassroots level, the Health Systems Trust (HST), in collaboration with provincial health departments, initiated a pilot programme of "bottom-up" support to, at first, only a selected number of districts (as pilot sites). This programme is known as the Initiative for Sub-district Support (ISDS) (Health Systems Trust, 1997:2). The ISDS embodies a deliberate, systematic programme of support to district and sub-district health services, without which districts may remain as administrative entities, rather than agents of optimal health care. ISDS support consist of seven components, which are customised to respond to the needs of each site. The components include research, evaluation, communication, technical support, information, facilitation and participation (Engelbrecht, 1997:2).

\section{Aim and objectives of the} research

As part of the research component of the ISDS programme in Bothaville sub-district in the Free State, the Centre for Health Systems Research \& Development was approached by the ISDS team there to monitor the implementation of a new mobile clinic system. Previously, three mobile clinic teams provided primary health care ( $\mathrm{PHC}$ ) on a three monthly basis to the farm community by visiting 431 farms and 75 farm schools. This changed towards the end of October 1997 and the mobile teams now visit 35 mobile visiting points, situated on farms in the district, from which $\mathrm{PHC}$ is provided to people working and living in rural areas.

The general aim of the study was to aid in the improvement of health care delivery to the rural community of Bothaville subdistrict, as well as to better facilitate the implementation of the DHS by providing baseline information on the current health care situation to the relevant managers and governors. The main objective of the study was to evaluate the current system of health care provision to the rural community in terms of its rural coverage, the disease profile catered for, the quality of care provided, and the referral system and its constraints. In this regard it was also important to reflect on differences between the previous and the new system of mobile health care.
This article will concentrate on the views of public health workers regarding $\mathrm{PHC}$ services, as well as other inter-facility health care issues.

\section{Methodology}

Personnel from all public health services in the Bothaville magisterial district were included in the survey by means of purposive sampling. These services are the PHC clinic, the three Local Authority (LA) clinics in Bothaville and Kgotsong, the Bothaville Hospital, District Surgeon (DS) Services and Emergency (ambulance) Services in Bothaville. The Environmental Health Officer of the district has also been consulted. More specifically the study population comprised of professional nurses based at the fixed clinics $(n=3)$, mobile clinics $(n=3)$, district medical officer's surgery $(n=1)$ and hospital $(n=4)$, as well as emergency service personnel $(n=3)$, district medical officers $(n=3)$ and the district's environmental health officer $(n=1)$. In total eighteen health care professionals have been interviewed by means of semi-structured personal interviews. Data was thus qualitatively collected. Interviews were conducted in either English or Afrikaans, depending on the preference of the respondent. Data was qualitatively analysed and the report was written by researchers from the Centre for Health Systems Research \& Development.

Results

\section{Evaluation of the previous and current systems of mobile health}

The main advantage of the previous system of mobile health pertained to the fact that all rural dwellers received $\mathrm{PHC}$ at home and immunisations were provided at all farm schools. The main disadvantages were that PHC was provided on a three monthly basis and that uncertainties surrounded the actual mobile clinic visiting dates. An additional shortcoming was stated to be the time consuming nature of the distances (sometimes under poor weather conditions) the $\mathrm{PHC}$ personnel had to travel.

It was indicated that some of these shortcomings have been rectified by the implementation of the visiting point system, since PHC services are currently rendered on a monthly basis. Visiting point dates are furthermore pre-planned and disseminated to people living in rural areas. Weather conditions have less of an influence on the rendering of services, since only larger roads are used for travelling. PHC providers also travel less, thus time is saved. Since the professional nurses now work in teams, difficulties such as breakdowns and uncertain health conditions are more easily addressed. The PHC providers moreover stated that, in contrast to the previous system of mobile health care, clinic activities are more routinised, since the service currently functions according to a strict time and date schedule. As to the disadvantages of the mobile visiting point system, respondents noted that it does not reach all (potential) clients living in rural areas, since people not living on farms that serve as visiting points have to travel to the nearest point. Respondents emphasised that transportation facilities, e.g. busses and taxis, in rural areas are inadequate to provide in this need. Additionally, it was argued that, since PHC personnel now provide chronic medication to rural dwellers, doctors have little to no control over fluctuations in chronic conditions. Furthermore, the higher patient load does not provide for individual attention and health education therefore suffers. Contact with many farmers whose farms do not serve as visiting points, has also been lost. 
Planning for the implementation of the new mobile clinic system

Some respondents felt that inadequate planning was done before the new system of mobile health was implemented. $\mathrm{PHC}$ personnel were firstly criticised for insufficient consultation with farmers and the rural community on the location of visiting points and secondly for poor information dissemination. However, it should be kept in mind that, at the time of planning and implementation, large parts of the district had no access to telephones, since telephone cables have been stolen. Although information regarding the change in mobile health systems has been disseminated to local farmer unions, not all farmers are members of such organisations. Personnel from one LA clinic complained that they have not sufficiently been informed on the change, since their facility was overutilised during the implementation of the new system.

\section{Effects of the change in mobile health systems}

The majority of respondents indicated that the change in the mobile health system has been for the better for people living and working in rural areas. Reasons consisted of the introduction of a fixed visiting schedule and the fact that more clients are seen on a regular basis. It should be noted that, compared to the total of 9228 headcount visits for 1997,6036 headcount visits have been recorded for the first quarter of 1998 only (Department of Health: Ticksheet Data, 1997; Bothaville PHC clinic, Daily Register 1998). It was also noted that chronic patients currently obtain prescriptions at the visiting points instead of having to travel to town on a regular basis.

Those opposed to the change in the mobile health system based their arguments on the problem of transportation to the nearest visiting point and the fact that many rural dwellers are confused about the change. As to the effects of the new mobile health system on other public health facilities, respondents stated that it either had no influence or that the situation at their health facilities has improved. This was mainly due to a decrease in the number of rural clients seen at health facilities in town. One respondent from the District Medical Officer (DMO) surgery complained that this decrease in the number of patients implies a decrease in his monthly income for seeing public patients.

\section{The role of farmers/spouses in the health care of the rural community}

Except for one LA clinic in Kgotsong, all respondents indicated that farmers regularly take farm workers to health facilities in town rather than allowing them to utilise mobile health services. The DMO interviewed stated that farmers are willing to pay for DMO services, because they are ensured of quality health services being rendered, which they are not always so sure of at the mobile clinics. Additionally, the time-consuming nature of the referral system has a negative influence on productivity on their farms. It was also stated that farmers have easier access to follow-up information from doctors than from the mobile clinic personnel. Respondents also noted on the convenience of taking rural dwellers to health facilities in town when a farmer/spouse plans to go to town for business. Respondents from LA clinics indicated that it is inevitable for farmers to bring farm workers, who fall ill between mobile clinic visits, to health facilities in town. However, the hospital personnel felt that some farmers/spouses are not adequately informed on the health referral system, since some take rural dwellers to the hospital instead of adhering to the referral system. The ambulance personnel furthermore complained that some farmers call for an emergency vehicle in cases of minor ailments that could have been treated successfully at a PHC or LA clinic. Respondents also indicated that many farmers still show a lack of interest in the health care of people working and living in rural areas. Those farmers whose farms do not serve as visiting points are generally dissatisfied with the change in mobile health care delivery.

\section{Referral issues}

Respondents were aware of many patients experiencing transportation problems when referred to a health facility in town. This was ascribed mainly to inadequate transport facilities and farmers' unwillingness and/or lack of time to provide transportation to referred patients. Due to the fragmented nature of public health services in the district, many patients, especially the elderly, find it difficult to move from one facility to the other.

PHC personnel are furthermore not allowed to refer cases of emergency directly to the hospital. They felt that this should change, because in cases of emergency, it is disadvantageous to the health of a patient to have to attend the DMO before being admitted to hospital. Health care professionals further complained that insufficient information is received back on the treatment of a referred patient, something which could be crucial in the further treatment of a referred back patient.

Dissemination of health information

Pamphlets distributed at central places, face-to-face consultations and the local newspaper and radio station were indicated to be the main sources of health information dissemination in the Bothaville sub-district. However, the communication of health information to rural communities remains problematic. This is mainly due to vast distances and inadequate transportation facilities. Illiteracy also plays a large role. Still, numerous informal information channels exist and health care providers often telephone a farmer/spouse if they need to communicate with patients. Sesotho and seTswana speaking staff members act as translators when language barriers are encountered.

\section{Community involvement in public health care}

A lack of community participation and involvement in health matters prevailed. Respondents from two LA clinics confirmed the existence of clinic committees in which community members could actively participate. Still, community involvement is poor. It was also reported that a representative from the farm schools has been appointed, but that this person, if in attendance, never provides any input. The majority of respondents indicated that clinic committees, hospital boards, community health forums and district facilitating committees are valuable structures to promote community involvement. It appears, however, that these structures are absent or do not operate adequately. It was additionally stated that, since most health committees are poorly organised, health care professionals often experience these meetings as a waste of time.

\section{Problems among health care facilities}

A major problem among health care facilities in Bothaville and Kgotsong has been identified as a lack in communication and co-operation. Contributing to this problem is the fragmented nature of health services. This results in duplication of prescriptions and an inability to keep record of an individual client. Health services are not only physically fragmented, but also resort under different authorities, which impedes proper 
co-ordination. Due to this fragmentation, confusion exists among personnel concerning their responsibilities. In addition, interpersonal friction exist among professional nurses from various health facilities. This was described as being caused by jealousy among nurses, a problem that has been in existence for quite some time. The lack of co-ordination of tasks given to ambulance personnel was also emphasised.

All respondents stated that they are aware of the "Co-ordinating Forum for Health Services in Bothaville". Its function was seen as improving communication between and solving of problems among the different health care facilities in Bothaville/ Kgotsong. It should be noted, however, that only one of the three doctors interviewed once attended a Forum meeting. Some respondents believed that the Forum was fulfilling its purpose, while others felt that the only action taken by the Forum is the allocation of personnel between various services. Another respondent complained that, despite the establishment of the Forum, the division between personnel from the different authorities persists

Integration of public health care services

All respondents felt that an integration of Bothaville/Kgotsong's and the provincial public health care services is possible. The majority of respondents shared the notion that only one health authority should manage all public health services. However, no consensus as to which authority (LA or the Provincial Department of Health) prevailed. It was furthermore stated that careful negotiation and planning should precede such an integration process. Important hampering factors in the integration of health services were identified as differences in internal policies, service conditions and salaries. Some respondents felt that the proposed integration could cause conflict between concerning parties, since each is trying to protect its own (financial) interest in the provision of health care. Communication between and (negative) attitudes of some health care professionals could also prove detrimental to an integration of health services. One major advantage of an integration was viewed as standardised regulations being executed by one health authority which will lead to a decline in inter-facility conflict. The rotation of personnel to positions where they are needed most (e.g. nurses being on leave or attending courses) would also be facilitated. An integrated health care system also implies better control and management of health and patient related information. In addition, if all health facilities were housed under one roof, (referred) patients would not have to travel from one health facility to another. An integrated health service would also ensure continuity, since patients would not feel that they are cared for only by some health care services.

\section{Recommendations}

Respondents made the following recommendations regarding the improvement of health care delivery in the Bothaville sub-district:

- More visiting points should be established throughout the district.

- A more serious effort should be undertaken to involve farmers in rural health matters, especially in relation to information dissemination and transportation of referred patients. They also need to be provided with more information pertaining to the referral system.

- A better transportation infrastructure in rural areas needs to be established. The possibility of transportation services between farms, co-inciding with mobile visiting dates, could be looked at. Some respondents indicated that a state funded transportation system would prove the best solution.
- Structures, such as community health forums, should be well organised to promote community involvement and participation.

- PHC providers should develop a more thorough and structured system of information dissemination to create a greater awareness on the visiting schedule, as well as the location of visiting points

- An optimal feedback system should be established to promote communication between different health services. A further suggestion was that a system of "patient held cards" or "carry cards" should be used by all health providers.

- One health authority should prevail and standardised service conditions, regulations and benefits should apply to all health providers in the public sector. It was furthermore stated that an integration of public health services would absolve the conflict among health care professionals

\section{Conclusion}

The main conclusion drawn from the research is that the new mobile clinic visiting point system provides $\mathrm{PHC}$ on a more regular basis (i.e. monthly) than the previous system. The main obstacle of the new system was identified as transport to visiting point farms especially in the case of the old and very ill. These and other advantages/disadvantages are depicted below in Table 1. Disadvantages of the new system could be overcome if close attention is paid to the recommendations drawn from the research. Proper and appropriate communication and relationships between farm workers, farm owners and mobile clinic personnel will further facilitate solutions to be worked out regarding problems experienced.

\section{References}

African National Congress. 1994a. A national health plan for South Africa. Johannesburg: African National Congress.

African National Congress. 1994b. The reconstruction and development programme. Cape Town: African National Congress.

Daily register data. 1998. Bothaville PHC clinic.

Engelbrecht, B. 1997. Provincial report: lessons from the Free State. DHS News, 2(2):2.

Free State Department of Health. 1998. Implementing a district-based health care system in the Free State: a framework for a district health authority. Bloemfontein: Free State Provincial Government.

Government Gazette. No. 17910. 16.04.1997. Health Act (Act 667 of 1997). Pretoria: Government Printer.

Health Systems Trust. 1997. A pocket guide to District Health Care in South Africa. Durban: Health Systems Trust.

Janse van Rensburg, E., Steyn, F., Van Rensburg, D., Matebesi, Z., O'Brien, M. \& Heunis, C. 1998. Improving health care to the farm community in the Bothaville district. Durban: Initiative for Sub-District Support - Health Systems Trust.

Ticksheet data. 1997. Free State Department of Health: Information Directorate: Specialised Services.

Van Rensburg, D., O'Brien, M., Steyn, F., Van Rensburg, E. \& Matebesi, Z. 1998. The health of Tshepo: a guide for managers and governors. Durban: Health Systems Trust - ISDS 


\begin{tabular}{|c|c|}
\hline Previous system & Visiting point system \\
\hline \multicolumn{2}{|c|}{ Advantages } \\
\hline $\begin{array}{l}\text { All rural dwellers received health care at home. } \\
\text { - Immunisations were provided at all farm schools. }\end{array}$ & $\begin{array}{l}\text { - Health services are monthly available. } \\
\text { - } \quad \text { Visiting dates are pre-planned and disseminated } \\
\text { (strict time and date schedules prevail). } \\
\text { - Whether conditions have less of an influence since } \\
\text { mobile units travel only on larger roads. } \\
\text { - Time is saved on travelling. } \\
\text { Health care providers work in teams, and break } \\
\text { downs and uncertainties about health conditions are } \\
\text { more easily addressed. } \\
\text { Chronic prescriptions are provided monthly. }\end{array}$ \\
\hline \multicolumn{2}{|c|}{ Disadvantages } \\
\hline $\begin{array}{l}\text { - Health care was provided on a three-monthly ba- } \\
\text { sis. } \\
\text { Weather conditions influence the availability of } \\
\text { health care services. } \\
\text { - } \quad \text { Distances to be travelled were time consuming. } \\
\text { No clear visiting dates could be provided to rural } \\
\text { dwellers. } \\
\text { Chronic prescriptions had to be obtained from } \\
\text { health facilities in town. } \\
\text { - Some clients made use of health services in town. }\end{array}$ & $\begin{array}{l}\text { - Not all rural dwellers depending on PHC are } \\
\text { reached. } \\
\text { Transport problems are experienced by clients who } \\
\text { have to travel to the nearest visiting point. } \\
\text { Doctors have little control over fluctuations in chronic } \\
\text { conditions. } \\
\text { - The higher patient load does not provide for indi- } \\
\text { vidual attention and health education suffers. } \\
\text { Contact with farmers whose farms do not serve as } \\
\text { visiting points was lost. }\end{array}$ \\
\hline
\end{tabular}

